\title{
Virulence genes and genotypes of Staphylococcus aureus from blood of Thai patients
}

\author{
Aroonlug Lulitanond ${ }^{\mathrm{a}, *}$, Ratdawan Kanyota ${ }^{\mathrm{b}}$, Chulapan Engchanil ${ }^{\mathrm{c}}$, Aroonwadee Chanawong ${ }^{\mathrm{a}}$, \\ Chotechana Wilailuckana $^{\mathrm{a}}$, Ratree Tavichakorntrakool ${ }^{\mathrm{a}}$, Pirom Puang-ngern ${ }^{\mathrm{d}}$, Pipat Sribenjalux ${ }^{\mathrm{a}}$ \\ ${ }^{a}$ Centre for Research and Development of Medical Diagnostic Laboratories, \\ Faculty of Associated Medical Sciences, Khon Kaen University, Khon Kaen 40002 Thailand \\ b Graduate School, Faculty of Associated Medical Sciences, Khon Kaen University, \\ Khon Kaen 40002 Thailand \\ c Research and Diagnostic Centre of Emerging Infectious Diseases and Department of Microbiology, \\ Faculty of Medicine, Khon Kaen University, Khon Kaen 40002 Thailand \\ d Clinical Microbiology Laboratory Unit, Srinagarind Hospital, Faculty of Medicine, Khon Kaen University, \\ Khon Kaen 40002 Thailand
}

*Corresponding author, e-mail: arolul@kku.ac.th

Received 9 Nov 2014

Accepted 7 Jul 2015

\begin{abstract}
Staphylococcus aureus is the most common cause of nosocomial fevers. We investigated the virulence genes and genotypes of $S$. aureus strains isolated from bloodstream infections of patients in a Thai teaching hospital. Thirtythree methicillin-resistant $S$. aureus (MRSA) and 52 methicillin-susceptible $S$. aureus (MSSA) collected during 19971998, and 29 MRSA and 52 MSSA strains collected during 2010-2011 were studied. Susceptibility to 8 antimicrobials was determined using an agar dilution method. Twelve virulence genes were detected by polymerase chain reaction. The bacterial strains were typed by SCCmec, agr, spa, and multilocus sequence typing. The majority of the MSSA isolates were susceptible to almost all antimicrobials tested, whereas the MRSA isolates were resistant to more than 3 of the antimicrobials tested. The hla-sea was the most common virulence gene profile in the MRSA isolates from both periods (46\% in 1997-1998, 31\% in 2010-2011), and hla alone was the most common pattern in the MSSA isolates (56\% in 1997-1998, 35\% in 2010-2011). The S. aureus isolates in 2010-2011 contained more virulence gene profiles than those in 1997-1998. All MRSA isolates from 1997-1998 carried SCCmec III-agr I, whereas those in 2010-2011 carried SCCmec III-agr I (48\%) and SCCmec type II-agr II (31\%). No specific virulence genes or genotypes of the isolates related to a poor clinical outcome were found.
\end{abstract}

KEYWORDS: bacteraemia, SCCmec, spa type, MLST

\section{INTRODUCTION}

Blood stream infection is a crucial life threatening condition. Staphylococcus aureus was the most common cause of a fever among patients admitted in the hospital ${ }^{1}$. Persistent $S$. aureus bacteraemia often results in longer hospital stays, excessive medical treatment costs, and ineffective chemotherapy with potential side effects, poor outcomes, and even death ${ }^{2,3}$. S. aureus produces several virulence factors, including surface associated adhesins, enzymes and exotoxins, which may contribute to its invasive potential and pathogenicity ${ }^{4}$. Clinical outcomes can vary depending on the $S$. aureus strain responsible for the infection. For example, the USA300 genotype has been associated with an increase in hospital mortality ${ }^{3}$. Despite the availability of effective antimicrobial therapy, the mortality rate among patients with $S$. aureus bacteraemia can be as high as $50 \%{ }^{5}$. The mortality rate of methicillinresistant $S$. aureus (MRSA) bacteraemia was previously shown to be higher than that of methicillinsusceptible $S$. aureus (MSSA) (67\% versus $46 \%$ in Thailand $^{6}$ and $50 \%$ versus $28 \%$ in Argentina ${ }^{1}$ ). Various clones of $S$. aureus strains, especially of MRSA, have been reported in many countries ${ }^{2,7}$. The majority of $S$. aureus infections in Thailand were related to hospitals, and most of them were clonal lineages of ST239-SCCmec III, with a minority of the strains belonging to the ST5-SCCmec II lineage ${ }^{8}$. However, the genotypes of $S$. aureus strains from blood infections in Thailand have not yet been 
reported. The molecular characteristics of $S$. aureus strains isolated from bacteraemia patients in a teaching hospital in North-eastern Thailand during 1997 and 1998 and during 2010 and 2011 were investigated. Their virulence gene profiles, specific genotypes and clinical outcomes were analysed to elucidate the epidemiological features present in both periods of times. The understanding of bacterial properties and their genetics may be helpful in the management of $S$. aureus bacteraemia patients and infection control.

\section{MATERIALS AND METHODS}

\section{Bacterial strains}

A total of 166 S. aureus samples were isolated from the blood of individual patients in Srinagarind Hospital, Khon Kaen University, Thailand. The samples consisted of 85 isolates (33 MRSA and 52 MSSA) collected during July 1997 and October 1998 and 81 isolates (29 MRSA and 52 MSSA) during October 2010 and September 2011. All the isolates were identified by Gram staining and biochemical testing (catalase, coagulase, DNase, and mannitol fermentation), and were confirmed by the PCR detection of either femA or nuc gene ${ }^{9}$. The MRSA isolates were identified also by PCR to detect the mecA gene ${ }^{10}$. The demographic data of the patients and the clinical information for the isolates collected in 2010 2011 were reviewed retrospectively from patient charts. This study was conducted in accordance with the declaration of Helsinki. It was approved by the Ethics Committee of Khon Kaen University (project number HE542113).

\section{Antimicrobial susceptibility testing}

The minimum inhibitory concentrations (MICs) of 8 antimicrobials (Sigma Chemicals); vancomycin (VA), ofloxacin (OF), sulphamethoxazole/trimethoprim, (SXT), tetracycline (TE), erythromycin (ER), oxacillin (OX), cefoxitin (FOX), and gentamicin (GN), were determined by the agar dilution method and the results were interpreted according to the CLSI breakpoints ${ }^{11}$.

\section{Virulence gene detection}

Twelve virulence-associated genes, including staphylococcal enterotoxin (sea, seb, sec, sed, see, seg, seh, sei, sej), $\alpha$-haemolysin (hla), toxic shock syndrome toxin-1 (tst), and Panton-Valentine leukocidin toxin (lukSF-PV), were detected according to the methods described previously ${ }^{12-14}$.

\section{Strain typing}

All the isolates were subjected to agr typing by multiplex PCR ${ }^{15}$. In addition, the SCCmec typing was performed for the MRSA isolates by multiplex $\mathrm{PCR}^{10}$. Nine representatives of the isolates in each group were randomly selected to process further for spa typing which was designated by using the Ridom StaphType program (www.ridom.de) according to a previous report ${ }^{16}$ and multilocus sequence typing (MLST) ${ }^{17}$. The nucleotide sequences of the 7 house keeping gene loci in MLST were concatenated, and a phylogenetic tree was produced using the PhyML program (v3.0 aLRT).

\section{Statistical analysis}

The data were analysed with SPSS STATISTICS 19. Categorical variables were compared using the Chi squared test or Fisher's exact test and the MannWhitney U test for non-normally distributed variables; $p<0.05$ was considered to be statistically significant.

\section{RESULTS}

\section{Antimicrobial susceptibility}

The majority of the MSSA isolates were susceptible to OX, FOX, ER, GN, OF, SXT, TE, and VA $(96,87$, $96,81,83,38,60$, and $100 \%$, respectively, for isolates in 1997-1998 and 100, 75, 92, 100, 98, 94,54 , and $100 \%$ were susceptible in 2010-2011). All the MRSA isolates in 1997-1998 were however resistant to OX, FOX, ER, and GN whereas 3, 3, 3 , and $100 \%$ were susceptible to OF, SXT, TE, and VA, respectively. Similarly, all the MRSA isolates in 2010-2011 were resistant to OX and FOX, while 3, $14,3,56,7$, and $100 \%$ were susceptible to ER, GN, OF, SXT, TE, and VA, respectively (Table 1). All the oxacillin and cefoxitin non-susceptible MSSA strains

Table 1 Antimicrobial susceptibility of $S$. aureus from blood infection in Northeast Thailand.

\begin{tabular}{lccccccccc}
\hline Samples $(n)$ & \multicolumn{6}{c}{ Antimicrobials (\% susceptible) ${ }^{\dagger}$} \\
\cline { 2 - 10 } & OX & FOX & ER & GN & OF & SXT & TE & VA \\
\hline MSSA 1997-98 (52) & $96^{*}$ & $87^{*}$ & 96 & 81 & 83 & 38 & 60 & 100 \\
MSSA 2010-11 (52) & 100 & $75^{*}$ & 92 & 100 & 98 & 94 & 54 & 100 \\
MRSA 1997-98 (33) & 0 & 0 & 0 & 0 & 3 & 3 & 3 & 100 \\
MRSA 2010-11 (29) & 0 & 0 & 3 & 14 & 3 & 56 & 7 & 100 \\
\hline
\end{tabular}

$\dagger$ OX, oxacillin; FOX, cefoxitin; ER, erythromycin; GN, gentamicin; OF, ofloxacin; SXT, sulphamethoxazole/trimethoprim; TE, tetracycline; VA, vancomycin.

* the resistant isolates had border-line MICs to OX and/or FOX. 
Table 2 Virulence associated gene profiles, genotypes and clinical outcomes of S. aureus bacteraemia patients in 19971998 and 2010-2011.

\begin{tabular}{|c|c|c|c|c|c|c|c|c|c|}
\hline \multirow{3}{*}{ Virulence gene profiles } & \multirow{3}{*}{ No. $(\%)$} & \multicolumn{6}{|c|}{ MRSA } & \multicolumn{2}{|c|}{ Clinical outcomes } \\
\hline & & \multicolumn{2}{|c|}{ SCCmec II } & \multicolumn{3}{|c|}{ SCCmec III } & \multirow{2}{*}{$\frac{\text { SCCmec IX }}{a g r \text { II }}$} & \multirow{2}{*}{$\begin{array}{l}\text { Septic } \\
\text { shock }\end{array}$} & \multirow[t]{2}{*}{ Poor } \\
\hline & & $\operatorname{agr} \mathrm{I}$ & $\operatorname{agr}$ II & $\operatorname{agr} \mathrm{I}$ & $\operatorname{agr}$ II & agr III & & & \\
\hline \multicolumn{10}{|l|}{ MRSA 2010-2011: $(n=29)$} \\
\hline - hla, sea & $10(34)$ & $1(3)$ & $7(24)$ & $9(31)^{\mathrm{a}}$ & & & & $3(10)$ & $6(21)$ \\
\hline - hla, seb, seg, sei, tst & $8(28)$ & & & & $1(3)$ & & & $2(7)$ & $6(21)$ \\
\hline - hla & $6(21)$ & & & $6(21)^{\mathrm{b}}$ & & & & $3(10)$ & $2(7)$ \\
\hline- sea & $1(3)$ & & & $1(3)$ & & & & & \\
\hline - hla, seg, sei, tst & $2(7)$ & & & $1(3)^{c}$ & & & $1(3)^{d}$ & & $1(3)$ \\
\hline - hla, seb & $1(3)$ & & $1(3)$ & & & & & & \\
\hline - hla, seb, sec, seg, sei, tst & $1(3)$ & & $1(3)$ & & & & & $1(3)$ & $1(3)$ \\
\hline \multicolumn{10}{|l|}{ MSSA 2010-2011: $(n=52)$} \\
\hline - hla & $18(35)$ & & & $16(31)$ & $2(4)$ & & & $1(2)$ & $4(8)$ \\
\hline - hla, tst & $5(10)$ & & & $1(2)$ & $1(2)$ & $3(6)$ & & $1(2)$ & \\
\hline - hla, sea & $4(8)$ & & & $2(4)$ & & $2(4)$ & & $1(2)$ & $1(2)$ \\
\hline - hla, seb, seg, sei, tst & $1(2)$ & & & & $1(2)$ & & & & \\
\hline - hla, seb, seg, sei & $1(2)$ & & & & $1(2)$ & & & & $1(2)$ \\
\hline - hla, tst, lukSF-PV & $1(2)$ & & & $1(2)$ & & & & & \\
\hline - hla, seb, seg, sei, tst, lukSF-PV & $1(2)$ & & & & $1(2)^{\mathrm{e}}$ & & & & \\
\hline - hla, seb, tst & $1(2)$ & & & & & $1(2)$ & & & $1(2)$ \\
\hline - hla, seb, sec, seh, tst & $1(2)$ & & & & & $1(2)^{f}$ & & & \\
\hline - hla, seg, sei lukSF-PV & $1(2)$ & & & & $1(2)^{\mathrm{e}}$ & & & & \\
\hline - seb, seg, sei & $1(2)$ & & & & & $1(2)^{f}$ & & & $1(2)$ \\
\hline - seg, sei & $1(2)$ & & & & & $1(2)$ & & & \\
\hline - hla, seb, sec, seh, tst & $1(2)$ & & & & & $1(2)$ & & $1(2)$ & \\
\hline other various types (1 each) & 10 (19) & & & & $6(12)$ & $4(8)$ & & $1(2)$ & $2(4)$ \\
\hline not found & $5(10)$ & & & $5(10)$ & & & & $1(2)$ & \\
\hline \multicolumn{10}{|l|}{ MRSA 1997-1998: $(n=33)$} \\
\hline - hla, sea & $15(45)$ & & & $15(45)^{g}$ & & & & & \\
\hline - hla & $14(42)$ & & & $14(42)^{\mathrm{h}}$ & & & & & \\
\hline not found & $4(12)$ & & & 4 (12) & & & & & \\
\hline \multicolumn{10}{|l|}{ MSSA 1997-1998: $(n=52)$} \\
\hline - hla & $29(56)$ & & & $29(56)$ & & & & & \\
\hline - hla, sea & $14(27)$ & & & $14(27)^{\mathrm{i}}$ & & & & & \\
\hline - hla, sea, lukSF-PV & $5(10)$ & & & $5(10)$ & & & & & \\
\hline - hla, lukSF-PV & $4(8)$ & & & $4(8)^{j}$ & & & & & \\
\hline
\end{tabular}

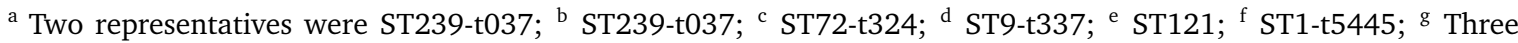
representatives were ST239-t037; ${ }^{\mathrm{h}}$ Two representatives were ST239-t037; ${ }^{\mathrm{i}}$ Two representatives were ST88; ${ }^{\mathrm{j}}$ Two were ST121.
}

yielded border-line MIC values which may be due to the hyper-production of penicillinase.

\section{Virulence genes}

The distribution of virulence genes in $S$. aureus isolates and genotypes are summarized in Table 2 . Of the 12 virulence-associated genes, hla was the most common virulence gene among the isolates from both periods at a frequency of $88 \%$ in MRSA and $100 \%$ in MSSA in 1997-1998 and $93 \%$ in MRSA and $81 \%$ in MSSA in 2010-2011. The next most common virulence gene was sea $(45 \% / 37 \%$ of MRSA/MSSA isolates in 1997-1998 and 38\%/11\% of MRSA/MSSA isolates in 2010-2011). The MRSA and MSSA isolates from 1997-1998 had 2 and 4 virulence-gene profiles, respectively, whereas those in 2010-2011 carried 7 and 24 profiles in the MRSA and MSSA groups, respectively. Among the MRSA isolates, the sea-hla profile was the most common profile (45\% in 1997-1998 and 34\% in 20102011). In contrast, among the MSSA isolates, the hla singleton was the most common profile $(56 \%$ 
in $1997-1998$ and $35 \%$ in $2010-2011$ ). The tst gene was found only among the isolates from 20102011 (38\% and $22 \%$ of MRSA and MSSA isolates, respectively). The lukSF-PV gene was detected only in MSSA isolates (17\% in $1997-1998$ and $11 \%$ in 2010-2011).

\section{Strain typing}

agr typing: All the isolates from 1997-1998 were agr I, while the isolates in 2010-2011 showed various agr types. Of the 29 MRSA isolates from 20102011, 18 (62\%) were $a g r \mathrm{I}$, and 11 (38\%) were $a g r$ II. Among the 52 MSSA isolates from 2010-2011, agr I (48\%) was the most prevalent followed by agr III (27\%), and agr II (25\%).

SCCmec typing: Using a combination of the mec gene complex class and the $c c r$ gene complex type, all 33 MRSA isolates in 1997-1998 were SCCmec III, whereas the MRSA isolates in 2010-2011 carried SCCmec III (62\%), SCCmec II (38\%), and SCCmec IX (3\%).

spa typing and MLST: Of the 5 representative MRSA isolates in 1997-1998, all were t037-ST239SCCmec III-agr I, 2 MSSA isolates were ST88-agr I, and 2 isolates were ST121-agr I. Among the 9 representative isolates in 2010-2011 (5 MRSA, 4 MSSA isolates), the MRSA isolates were spa type t037 ( 3 isolates), t324, and t337, whereas 2 MSSA isolates were spa type t5445. Combining the typing results, the MRSA isolates in 2010-2011 were t037ST239-SCCmec III-agr I (3 isolates), t324-ST72SCCmec III-agr I, and t337-ST9-SCCmec IX-agr II; while the MSSA isolates were ST121-agr II (2 isolates), and t5445-ST1-agr III (2 isolates). The spa types of $6 \mathrm{MSSA}$ isolates were undetermined. The phylogenetic tree of the sequence types found in this study is shown in Fig. 1.

\section{Clinical characteristics}

The patients' information was available only for the isolates from 2010-2011 (27 of 29 cases of MRSA

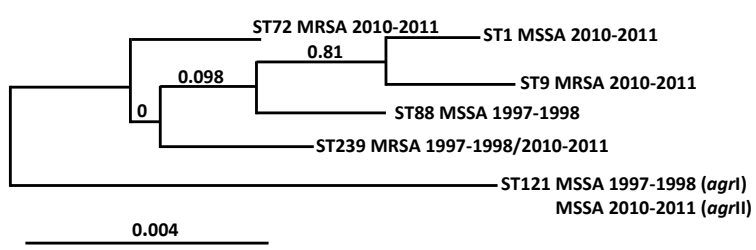

Fig. 1 Phylogenetic diversity of the sequence types detected among representative $S$. aureus strains collected in 1997-1998 and 2010-2011. infection and 49 of 52 cases of MSSA infection) and is summarized in Table 3 . Of the 27 patients infected with MRSA, 15 cases (56\%) were females, whereas 11 cases $(22 \%)$ of the MSSA infection group were females. The age of the patients ranged from newborn to 101 years (mean $\pm S D, 46 \pm 27$ ) in the MRSA group and from newborn to 82 years $(48 \pm 23)$ in the MSSA group. The underlying conditions of patients infected with MRSA and MSSA were comparable except that the prevalence of liver disease was significantly higher in MSSA group $(p=0.044)$. Regarding the clinical course and outcome of the patients, those infected with MRSA had significantly higher incidences of the following conditions than those infected with MSSA: hospital stay $>30$ days $(70 \%$ versus $29 \%, p=0.0007$, odds ratio $=5.9,95 \% \mathrm{CI}=2.1-16.6)$, poor outcome ( $52 \%$ versus $22 \%, p=0.01$, odds ratio $=3.7,95 \%$ $\mathrm{CI}=1.3-10.2)$ and septic shock (33\% versus $12 \%$, $p=0.03$, odds ratio $=3.5,95 \% \mathrm{CI}=1.1-11.5$ ). Cloxacillin only or cloxacillin combined with other antimicrobials was the most common drug used for the treatment of MSSA infection, whereas MRSA infections were most commonly treated with vancomycin. The mortality rates of patients infected with MRSA and MSSA were not significantly different $(p=0.41)$.

No specific virulence gene profile or specific genotype of the isolates was found to be related to any patient with septic shock or to a poor outcome ( $p=0.8$, data not shown).

\section{DISCUSSION}

Genotypic differences were observed among $S$. aureus isolates from several countries, and particular strains were associated with poor clinical outcomes. The PVL-positive community-acquired (CA) -MRSA isolates in Taiwan caused more serious infections in patients presented with non-multidrug-resistant MRSA bacteraemia, and most of the isolates were spa type t437-ST59 ${ }^{18}$. The MRSA strain USA300 was associated with increased mortality in the US ${ }^{19}$. In contrast, the isolates in the present study did not show specific virulence genes related to mortality or poor outcome. This may be due to the geographic differences between the strains or the different statuses of the patients. The most common virulence gene among both sample groups in this study was hla, similar to a previous report from Denmark $^{20}$. The toxin promotes cell lysis and induces inflammation, leading to critical diseases such as pneumonia and sepsis ${ }^{21}$. However, no significant clinical outcomes were observed relating 
Table 3 Clinical information of patients with S. aureus blood stream infection in 2010-2011.

\begin{tabular}{|c|c|c|c|c|c|}
\hline \multirow[b]{2}{*}{ Clinical characteristics } & \multicolumn{2}{|c|}{ S. aureus isolates } & \multirow[b]{2}{*}{ Odds ratio } & \multirow[b]{2}{*}{$95 \%$ CI } & \multirow[b]{2}{*}{$p$} \\
\hline & $\begin{array}{c}\text { MRSA } \\
n=29(\%)^{\mathrm{a}}\end{array}$ & $\begin{array}{c}\text { MSSA } \\
n=52(\%)^{\mathrm{b}}\end{array}$ & & & \\
\hline Male & $12(44)$ & $38(78)$ & 0.2 & $0.08-0.63$ & 0.004 \\
\hline Female & $15(56)$ & $11(22)$ & 3.1 & $1.1-8.3$ & 0.02 \\
\hline Age: median (range) & $51(\mathrm{NB}-101)^{*}$ & $50(\mathrm{NB}-82)$ & & & \\
\hline \multicolumn{6}{|l|}{ Underlying: } \\
\hline - Diabetes mellitus & $6(22)$ & $14(29)$ & 0.7 & $0.2-2.1$ & 0.54 \\
\hline - Hypertension & $6(22)$ & $13(27)$ & 0.7 & $0.2-2.3$ & 0.67 \\
\hline - Renal disease & $8(30)$ & $14(29)$ & 1.0 & $0.3-2.9$ & 0.92 \\
\hline - Heart disease & $3(11)$ & $4(8)$ & 1.4 & $0.2-6.8$ & 0.67 \\
\hline - Liver disease & 0 & $8(16)$ & 0.08 & $0.004-1.6$ & 0.10 \\
\hline - Malignancy & $2(7)$ & $8(16)$ & 0.4 & $0.08-2.0$ & 0.28 \\
\hline - Others & $5(19)$ & $8(16)$ & 1.1 & $0.3-3.9$ & 0.80 \\
\hline - No underlying & $2(7)$ & $8(16)$ & 0.4 & $0.08-2.0$ & 0.28 \\
\hline agr Type I & $18(62)$ & $26(50)$ & 1.7 & $0.6-4.7$ & 0.25 \\
\hline agr Type II & $11(38)$ & $13(25)$ & 1.9 & $0.7-5.1$ & 0.20 \\
\hline agr Type III & 0 & $13(25)$ & 0.4 & $0.002-0.8$ & 0.03 \\
\hline sCCmec Type II & $10(34)$ & & & & \\
\hline SCCmec Type III & $18(62)$ & & & & \\
\hline SCCmec Type IX & $1(3)$ & & & & \\
\hline \multicolumn{6}{|l|}{ Antibiotics: } \\
\hline - Cloxacillin ${ }^{c}$ & 0 & $29(59)$ & 0.01 & $0.0007-0.2$ & 0.002 \\
\hline - Vancomycin ${ }^{\mathrm{d}}$ & $23(85)$ & 7 (14) & 34.5 & $9.1-130.3$ & $<0.0001$ \\
\hline - Others & $4(15)$ & $13(27)$ & 0.4 & $0.1-1.6$ & 0.24 \\
\hline Duration $>30$ days in hospital & $19(70)$ & $14(29)$ & 5.9 & $2.1-16.6$ & 0.0007 \\
\hline \multicolumn{6}{|l|}{ Outcome: } \\
\hline - Septic shock & $9(33)$ & $6(12)$ & 3.5 & $1.1-11.5$ & 0.03 \\
\hline - Good & $4(15)$ & $26(53)$ & 0.1 & $0.04-0.5$ & 0.002 \\
\hline - Poor & $14(52)$ & $11(22)$ & 3.7 & $1.3-10.2$ & 0.01 \\
\hline - Death & $9(33)$ & $12(24)$ & 1.5 & $0.5-4.3$ & 0.41 \\
\hline - Co-infect w/ Gram neg. bacilli & 5 (19) & $9(18)$ & 1.0 & $0.3-3.3$ & 0.09 \\
\hline
\end{tabular}

to the strains containing hla gene compared to those without this gene. The sea gene was primarily found in the SCCmec III MRSA isolates (91\%), whereas tst was dominant in the SCCmec II isolates (72\%). These findings are similar to those reported by Kim et $\mathrm{al}^{22}$ and Hongsrichan et $\mathrm{al}^{23}$, suggesting that these virulence genes may be related to a certain SCCmec type. The seg and sei genes were detected within the same isolate with the majority were $a g r$ II (58\%). These results imply that the genes may be located on the same enterotoxin gene cluster $(e g c)^{24}$.

The lukSF-PV, a set of bicomponent genes, encodes the PVL toxin. The role of this toxin as a virulence factor was controversial because an ex- perimental study in mice showed that PVL did not contribute to the pathogenesis of staphylococcal infection $^{25}$. However, it has been shown to be related to necrotizing pneumonia and skin and soft tissue infections in human ${ }^{26}$. This syndrome was often found in CA-MRSA infections, which usually carry the SCCmec IV element ${ }^{27}$. This gene was rarely (less than 5\%) found in the hospital-acquired-MRSA strains which generally carry either the SCCmec I, II or III element ${ }^{28}$. In this study, the lukSF-PV gene was not found in any MRSA isolates. Most of the patients infected with lukSF-PV-carrying $S$. aureus isolates had good outcomes and did not develop necrotizing symptoms. Unfortunately, it was not possible to determine whether the isolates charac- 
terized in the present study were from communityor hospital-acquired infections.

The accessory gene regulator (agr) systems play a major role in controlling virulence factor production in S. aureus isolates and were classified into four different agr groups. In this study, agr IV was not found in any isolates, similar to what was observed in a previous report ${ }^{29}$, suggesting that the agr IV $S$. aureus isolate was not common. The agr III and IV groups were associated with tst and exfoliatin toxin production, respectively ${ }^{30,31}$. The tst gene was most common in the agr II $S$. aureus isolates (59\%), followed by the agr III (27\%) and agr I (14\%) isolates. Interestingly, most of the agr II and III isolates in this study carried more virulence genes (> 3 virulence genes) than the agr I isolates. In addition, the isolates that did not contain any of the assessed virulence genes were all agr I (Table 2). These data are similar to previous reports showing that most toxin-producing $S$. aureus strains were agr $\mathrm{II}^{32}$ or III $^{33}$.

The genotype of $S$. aureus isolates between the two periods was quite different. The MSSA isolates from 2010-2011 demonstrated a wider variety of virulence gene profiles and agr groups than those from 1997-1998. Likewise, all the MRSA isolates from 1997-1998 carried SCCmec III-agr I, which was thought to be a major clone in this hospital ${ }^{8}$, whereas all but one of the isolates from 2010-2011 contained either SCCmec II or III. The percentage of SCCmec II MRSA isolates from 2010-2011 was much higher than the previous report from the same hospital in 2002-2003 (34\% versus $2 \%)^{8}$, suggesting that the SCCmec III strain dominant in 1997-1998 was gradually replaced with the SCCmec II strain by 2010-2011. Moreover, an SCCmec IXagr II MRSA isolate that was recently isolated from a skin infection of an outpatient of this hospital ${ }^{34}$ was also detected in this study, suggesting that the SCCmec IX-agr II MRSA strain may be a new clone distributed in this hospital. The SCCmec IX MRSA strains were related to swine and products from swine $^{35}$. The source of this strain may be related to pig. The change of bacterial strains over time may be due to the change of the environmental selective pressure ${ }^{36}$ or to globalization. This situation was similar to one that occurred in Hungary in which ST239-SCCmec III was replaced by ST5- SCCmec II and ST228- SCCmec I between 1994 and $2004^{37}$, and in Japan the clone changed from ST30-SCCmec I or ST30-SCCmec IV in 1979-1980 to ST5-SCCmec II in $1999^{38}$. As far as we know, this is the first report describing the trend in the MRSA clonal change in
Thailand over the last decade.

The sequence types of isolates in this study belonged to different clonal complexes: ST1 (CC1), ST9 (CC9), ST88 (CC88), ST239 (CC8), and ST72 (CC1) suggesting that there are several $S$. aureus clones in this area. The ST121 MSSA and ST239t037 MRSA isolates were detected in both periods, indicating that they were endemic strains in this area. However, the ST121 strains from both periods carried different virulence genes and agr types which may be due to the horizontal transfer of the virulence genes among different strains. The ST88MRSA-III/IV was proposed to be a typical African clone but it was also reported sporadically around the world ${ }^{39}$. The ST88 MSSA isolates in this study may derive from different ancestor from that of the African clone. Comparison of the whole genome sequences or pulse field gel electrophoresis patterns of these strains would reveal their association.

Although the clinical data showed that the mortality rates of the patients infected with MRSA and MSSA were not significantly different, the MRSA-infected patients tended to stay in the hospital longer than the MSSA-infected cases ( $p=$ 0.0007). In summary, a temporal change was observed among the $S$. aureus strains isolated from blood stream infections of patients in a teaching hospital in Northeast Thailand between 1997 and 1998 and 2010-2011. The isolates from 20102011 carried more virulence genes and were more genetically diverse than those from 1997-1998.

Acknowledgements: This project was financially supported by Khon Kaen University under the Incubation Researcher Project (Fiscal year 2012). The authors thank the Centre for Research and Development of Medical Diagnostic Laboratories (CMDL), Faculty of Associated Medical Sciences, Khon Kaen University, and the Division of Research Administration, Khon Kaen University. We also wish to thank the staff of the Clinical Microbiology Laboratory at Srinagarind Hospital, Faculty of Medicine, Khon Kaen University for collecting the clinical isolates. We thank Yukifumi Nawa for his valuable suggestions.

\section{REFERENCES}

1. Stryjewski ME, Kanafani ZA, Chu VH, Pappas PA, Harding T, Drew LA, Benjamin DK Jr, Reller LB, et al (2009) Staphylococcus aureus bacteremia among patients with health care-associated fever. Am J Med 122, 281-9.

2. Robinson JO, Pearson JC, Christiansen KJ, Coombs GW, Murray RJ (2009) Community-associated versus healthcare-associated methicillin-resistant Staphylo- 
coccus aureus bactaeremia: a 10-year retrospective review. Eur J Clin Microbiol Infect Dis 28, 353-61.

3. Lewis T, Chaudhry R, Nightingale P, Lambert P, Das I (2011) Methicillin-resistant Staphylococcus aureus bacteremia: epidemiology, outcome, and laboratory characteristics in a tertiary referral centre in the UK. Int $J$ Infect Dis 15, 131-5.

4. Ferry T, Perpoint T, Vandenesch F, Etienne J (2005) Virulence determinants in Staphylococcus aureus and their involvement in clinical syndromes. Curr Infect Dis Rep 7, 420-8.

5. Porto JP, Santos RO, Gontijo Filho PP, Ribas RM (2013) Active surveillance to determine the impact of methicillin resistance on mortality in patients with bacteremia and influences of the use of antibiotics on the development of MRSA infection. Rev Soc Bras Med Trop 46, 713-8.

6. Nickerson EK, Hongsuwan M, Limmathurotsakul D, Wuthiekanun V, Shah KR, Srisomang P, Mahavanakul W, Wacharaprechasgul T, et al (2009) Staphylococcus aureus bacteraemia in a tropical setting: Patient outcome and impact of antibiotic resistance. PLOS ONE 4, e4308.

7. Yao D, Yu FU, Qin ZQ, Chen C, He SS, Chen ZQ, Zhang XQ, Wang LX (2010) Molecular characterization of Staphylococcus aureus isolates causing skin and soft tissue infections (SSTIs). BMC Infect Dis 10, 133.

8. Lulitanond A, Chanawong A, Sribenjalux P, Wilailuckana C, Kaewkes W, Vorachit M, Ito T, Hiramatsu K (2010) Preliminary report of SCCmec types and antimicrobial susceptibilities of methicillin-resistant Staphylococcus aureus isolatesfrom a university hospital in Thailand. Southeast Asian J Trop Med Publ Health 41, 920-7.

9. Berger-Bachi B, Barberis-Maino L, Strassle A, Kayser FH (1989) FemA, a host-mediated factor essential for methicillin resistance in Staphylococcus aureus: molecular cloning and characterization. Mol Gen Genet 219, 263-9.

10. Kondo Y, Ito T, Ma XX, Watanabe S, Kreiswirth BN, Etienne J, Hiramatsu K (2007) Combination of multiplex PCRs for staphylococcal cassette chromosome mec type assignment: rapid identification system for mec, $c c r$, and major differences in junkyard regions. Antimicrob Agents Chemother 51, 264-74.

11. Clinical Laboratory Standards Institute (2010) Performance standards for antimicrobial susceptibility testing: Nineteenth information supplement, M100S19, Wayne, PA.

12. Monday SR, Bohach GA (1999) Use of multiplex PCR to detect classical and newly described pyrogenic toxin genes in staphylococcal isolates. J Clin Microbiol 37, 3411-4.

13. Cafiso V, Bertuccio T, Santagati M, Demelio V, Spina D, Nicoletti G, Stefani S (2007) agr-Genotyping and transcriptional analysis of biofilm-producing Staphyl- ococcus aureus. FEMS Immunol Med Microbiol 51, 220-7.

14. Lina G, Piemont $Y$, Godail-Gamot F, Bes M, Peter MO, Gauduchon V, Vandenesch F, Etienne J (1999) Involvement of Panton-Valentine leukocidin-producing Staphylococcus aureus in primary skin infections and pneumonia. Clin Infect Dis 29, 1128-32.

15. Lina G, Boutite F, Tristan A, Bes M, Etienne J, Vandenesch F (2003) Bacterial competition for human nasal cavity colonization: role of Staphylococcal agr alleles. Appl Environ Microbiol 69, 18-23.

16. Montesinos I, Salido E, Delgado T, Cuervo M, Sierra A (2002) Epidemiologic genotyping of methicillinresistant Staphylococcus aureus by pulsed-field gel electrophoresis at a university hospital and comparison with antibiotyping and protein A and coagulase gene polymorphisms. J Clin Microbiol 40, 2119-25.

17. Enright MC, Day NP, Davies CE, Peacock SJ, Spratt BG (2000) Multilocus sequence typing for characterization of methicillin-resistant and methicillinsusceptible clones of Staphylococcus aureus. J Clin Microbiol 38, 1008-15.

18. Wang JL, Wang JT, Chen SY, Hsueh PR, Kung HC, Chen YC, Chang SC (2007) Adult methicillin-resistant Staphylococcus aureus bacteremia in Taiwan: clinical significance of non-multi-resistant antibiogram and Panton-Valentine leukocidin gene. Diagn Microbiol Infect Dis 59, 365-71.

19. Kempker RR, Farley MM, Ladson JL, Satola S, Ray SM (2010) Association of methicillin-resistant Staphylococcus aureus (MRSA) USA300 genotype with mortality in MRSA bacteremia. J Infect 61, 372-81.

20. Bhakdi S, Tranum-Jensen J (1991) Alpha-toxin of Staphylococcus aureus. Microbiol Rev 55, 733-51.

21. Bubeck Wardenburg J, Patel RJ, Schneewind O (2007) Surface proteins and exotoxins are required for the pathogenesis of Staphylococcus aureus pneumonia. Infect Immun 75, 1040-4.

22. Kim JS, Song W, Kim HS, Cho HC, Lee KM, Choi MS, Kim EC (2006) Association between the methicillin resistance of clinical isolates of Staphylococcus aureus, their staphylococcal cassette chromosome mec (SCCmec) subtype classification, and their toxin gene profiles. Diagn Microbiol Infect Dis 56, 289-95.

23. Hongsrichan N, Wilailuckana C, Homchumpa P, Chanawong A, Wilachai C, Lulitanond A, Chaimanee P, Mutsikaphan P (2009) Prophage- and pathogenicity islands-associated virulence genes in Staphylococcus aureus isolated from patients in Srinagarind hospital. J Med Tech Phys Ther 21, 131-40.

24. Jarraud S, Peyrat MA, Lim A, Tristan A, Bes M, Mougel C, Etienne J, Vandenesch F, et al (2001) egc, a highly prevalent operon of enterotoxin gene, forms a putative nursery of superantigens in Staphylococcus aureus. J Immunol 166, 669-77.

25. Wardenburg JB, Palazzolo-Ballance AM, Otto M, Schneewind O, DeLeo FR (2008) Panton-Valentine 
Leukocidin is not a virulence determinant in murine models of community-associated methicillin-resistant Staphylococcus aureus disease. J Infect Dis 198, 1166-70.

26. Gillet $Y$, Issartel B, Vanhems P, Fournet JC, Lina G, Bes M, Vandenesch F, Piémont Y, et al (2002) Association between Staphylococcus aureus strains carrying gene for Panton-Valentine leukocidin and highly lethal necrotizing pneumonia in young immunocompetent patients. Lancet 359, 753-9.

27. Denis O, Deplano A, De Beenhouwer H, Hallin M, Huysmans G, Garrino MG, Glupczynski Y, Malaviolle X, et al (2005) Polyclonal emergence and importation of community-acquired methicillin-resistant Staphylococcus aureus strains harbouring PantonValentine leucocidin genes in Belgium. $J$ Antimicrob Chemother 56, 1103-6.

28. Hiramatsu K, Cui L, Kuroda M, Ito T (2001) The emergence and evolution of methicillin-resistant Staphylococcus aureus. Trends Microbiol 9, 486-93.

29. Moore PC, Lindsay JA (2001) Genetic variation among hospital isolates of methicillin-sensitive Staphylococcus aureus: evidence for horizontal transfer of virulence genes. J Clin Microbiol 39, 2760-7.

30. Deurenberg RH, Nieuwenhuis RF, Driessen C, London N, Stassen FR, van Tiel FH, Stobberingh EE, Vink C (2005) The prevalence of the Staphylococcus aureus tst gene among community- and hospital-acquired strains and isolates from Wegener's Granulomatosis patients. FEMS Microbiol Lett 245, 185-9.

31. Jarraud S, Lyon GJ, Figueiredo AM, Lina G, Vandenesch F, Etienne J, Muir TW, Novick RP (2000) Exfoliatin-producing strains define a fourth agr specificity group in Staphylococcus aureus. J Bacteriol 182, 6517-22.

32. Indrawattana $\mathrm{N}$, Sungkhachat $\mathrm{O}$, Sookrung $\mathrm{N}$, Chongsa-nguan M, Tungtrongchitr A, Voravuthikunchai SP, Kong-ngoen T, Kurazono H, et al (2013) Staphylococcus aureus clinical isolates: Antibiotic susceptibility, molecular characteristics, and ability to form biofilm. BioMed Res Int 2013, 314654.

33. Ji G, Beavis R, Novick RP (1997) Bacterial interference caused by autoinducing peptide variants. Science 276, 2027-30.

34. Lulitanond A, Ito T, Li S, Han X, Ma XX, Engchanil C, Chanawong A, Wilailuckana C, et al (2013) ST9 MRSA strains carrying a variant of type IX SCCmec identified in the Thai community. BMC Infect Dis 13, 214.

35. Vestergaard M, Cavaco LM, Sirichote P, Unahalekhaka A, Dangsakul W, Svendsen CA, Aarestrup FM, Hendriksen RS (2012) SCCmec type IX element in methicillin-resistant Staphylococcus aureus spa type t337 (CC9) isolated from pigs and pork in Thailand. Front Microbiol 3, 103.

36. Young BC, Golubchik T, Batty EM, Fung R, LarnerSvensson H, Votintseva AA, Miller RR, Godwin H, et al (2012) Evolutionary dynamics of Staphylococcus aureus during progression from carriage to disease. Proc Natl Acad Sci USA 109, 4550-5.

37. Conçeicão T, Aires-de-Sousa M, Füzi M, Tóth A, Pászti J, Ungvári E, van Leeuwen WB, van Belkum A, et al (2007) Replacement of methicillin-resistant Staphylococcus aureus clones in Hungary over time: a 10-year surveillance study. Clin Microbiol Infect 13, 971-9.

38. Ma XX, Ito T, Chongtrakool P, Hiramatsu K (2006) Predominance of clones carrying Panton-Valentine Leukocidin genes among methicillin-resistant Staphylococcus aureus strains isolated in Japanese hospitals from 1979 to 1985. J Clin Microbiol 44, 4515-27.

39. Schaumburg F, Alabi AS, Peters G, Becker K (2014) New epidemiology of Staphylococcus aureus infection in Africa. Clin Microbiol Infect 20, 589-96. 